\title{
Cultured Pearl Surface Quality Profiling by the Shell Matrix Protein Gene Expression in the Biomineralised Pearl Sac Tissue of Pinctada margaritifera
}

\author{
Blay Carole ${ }^{1,2}$, Planes Serge ${ }^{2}$, Ky Chin-Long ${ }^{1, *}$ \\ ${ }^{1}$ Ifremer, UMR EIO241, Labex Corail, Centre du Pacifique, BP 49, 98719 Taravao, Tahiti, French \\ Polynesia \\ 2 PSL Research University: EPHE-UPVD-CNRS, USR 3278 CRIOBE, Université de Perpignan, 52 \\ Avenue Paul Alduy, 66860 Perpignan Cedex, France \\ *Corresponding author : Chin-Long Ky, email address : chinky@ifremer.fr
}

\begin{abstract}
:
Nucleated pearls are produced by molluscs of the Pinctada genus through the biomineralisation activity of the pearl sac tissue within the recipient oyster. The pearl sac originates from graft tissue taken from the donor oyster mantle and its functioning is crucial in determining key factors that impact pearl quality surface characteristics. The specific role of related gene regulation during gem biogenesis was unknown, so we analysed the expression profiles of eight genes encoding nacreous (PIF, MSI60, PERL1) or prismatic (SHEM5, PRISM, ASP, SHEM9) shell matrix proteins or both (CALC1) in the pearl sac $(N=211)$ of Pinctada margaritifera during pearl biogenesis. The pearls and pearl sacs analysed were from a uniform experimental graft with sequential harvests at 3,6 and 9 months post-grafting. Quality traits of the corresponding pearls were recorded: surface defects, surface deposits and overall quality grade. Results showed that (1) the first 3 months of culture seem crucial for pearl quality surface determination and (2) all the genes (SHEM5, PRISM, ASP, SHEM9) encoding proteins related to calcite layer formation were over-expressed in the pearl sacs that produced low pearl surface quality. Multivariate regression tree building clearly identified three genes implicated in pearl surface quality, SHEM9, ASP and PIF. SHEM9 and ASP were clearly implicated in low pearl quality, whereas PIF was implicated in high quality. Results could be used as biomarkers for genetic improvement of $P$. margaritifera pearl quality and constitute a novel perspective to understanding the molecular mechanism of pearl formation.
\end{abstract}

Keywords : Biomineralisation, Relative gene expression, Pearl sac, Biomarkers, Pearl quality, Pinctada margaritifera 
Biomineralisation refers to the processes by which organisms form minerals. It is an extremely widespread phenomenon, leading to a variety of biological structures such as teeth, bone, otoliths, spicules,

http://eproofing.springer.com/journals_v2/printpage.php?token=FQrWiRjlm3CYq5f6... 26/03/2018 
shell and pearl (Lowenstam and Weiner 1989). In molluscs, although organic macromolecules, especially proteins, represent no more than $5 \%(w / w)$ of shell weight, they play key roles in nucleation, orientation, morphology, polymorphism and organisation of the calcium carbonate crystallites of the shell (Belcher et al. 1996; Zhan et al. 2015). The pearl oyster, which has the unique ability to produce pearls, is an ideal model animal to study biomineralisation. Structurally, the pearl oyster shell consists of two distinct calcified microlaminates, the inner aragonite nacreous layer, which is similar to the nacreous layer of pearls, and the outer calcite prismatic layer (Marin et al. 2007). Although both calcite and aragonite are constructed with calcium carbonate, they display distinctly different configurations and characters (Zhan et al. 2015). The accumulation of calcium carbonate as calcite and aragonite crystals is thought to be regulated by proteins secreted from the mantle (Funabara et al. 2014). To understand biomineralisation mechanisms, one must possess knowledge on the structures of the organic matrix components together with the entire process.

AQ4

Nucleated cultured pearl production from the Pinctada genus consists of three steps: (1) initial 2 years oyster grow out phase, (2) nucleus implantation and (3) about 2 years of culturing before harvest. Nucleus implantation is a delicate surgical operation where a trained technician inserts a round nucleus made of shell and a small piece of mantle from the outer mantle of a donor mollusc into a diverticulum of the gonad of a recipient oyster (Southgate 2008). Around the nucleus, a pearl sac (PS) is formed by proliferation of the outer mantle epithelial cells of the mantle graft (Inoue et al. 2010), which secretes successive nacre layers onto the nucleus. The established pearl sac consists of mucous cells containing large acidophilic granules and epidermal cells (Liu et al. 2012) that secrete proteins resulting in cultured pearl formation, a highly controlled biomineralisation process similar to development of inner shell regulated by the mantle (Zhan et al. 2015). The role of the pearl sac in nacreous layer biomineralisation is thought to mirror the role of the oyster mantle that was grafted (Arnaud-Haond et al. 2007; Wang et al. 2009; Inoue et al. 2010). The quality of Tahitian cultured black pearl is determined according to a wide range of criteria, including pearl classification grade, surface quality and lustre, shape, 
colour (bodycolor and overtone), darkness level and size (Tayalé et al. 2012; Ky et al. 2013). In French Polynesia, the production of cultured pearls of Pinctada margaritifera remains the most valuable export industry and is the second most important source of income after tourism (Ky et al. 2016). It has been estimated that only $5-10 \%$ of cultured pearls per harvest are of gem quality, but this small percentage accounts for about 95\% of a farm's income (Ellis and Haws 1999). Producing cultured pearls of high quality with $P$. margaritifera is one of the major challenges for the pearl industry in French Polynesia, making the process of biomineralisation of the nacreous layer of great economic interest. The regulation of shell matrix proteins in biomineralisation during the pearl culture and the impact of this process on pearl quality are research topics of high priority.

Many studies have focused on oyster shell formation because the nacreous layer of shells is structurally similar to the nacreous layer of pearls. Since the report of the first nacre-shell protein nacrein in 1996 (Miyamoto et al. 1996), dozens of shell matrix proteins have been found to contribute to the molecular mechanism underlying the development of shell and pearl, playing important roles in crystal nucleation, orientation, polymorph morphology (Gao et al. 2016). Some genes are involved in the formation of nacreous aragonite, such as PIF (Zhao et al. 2014), MSI60 (Sudo et al. 1997) and Pearlin (Suzuki and Nagasawa 2013; Miyashita et al. 2000; Montagnani et al. 2011) (Table 1). Other genes involved in prismatic calcite include Aspein (Tsukamoto et al. 2004; Takeuchi et al. 2008), Prismalin-14 (Suzuki et al. 2004; Suzuki and Nagasawa 2007) and the Shematrin family (Joubert et al. 2010; Marie et al. 2012). One gene, Nacrein, has been found in both the nacreous and prismatic layers of the shell (Miyamoto et al. 1996; Suzuki and Nagasawa 2013). The role of elaborate organic matrix of protein embedded in calcium carbonate crystals of either aragonite or calcite has been examined (Addadi and Weiner 1985; Belcher et al. 1996; Falini et al. 1996; Levi et al. 1998; Weiner and Hood 1975). Shell matrix is not formed simply by self-assembling silk-like proteins but by diverse proteins through complex assembly and modification processes that may involve haemocytes and exosomes (Zhang et al. 2012). Although other proteins have been isolated as matrix proteins from the 
prismatic and nacreous layers, it is not clear how these two layers are formed in molluscan shells (Funabara et al. 2014).

Table 1

Set of forward and reverse primers used for the biomineralisation gene expression

\begin{tabular}{|c|c|c|c|c|}
\hline $\begin{array}{l}\text { Primer } \\
\text { name }\end{array}$ & $\begin{array}{l}\text { Protein } \\
\text { name }\end{array}$ & Function & $\begin{array}{l}\text { GenBank } \\
\text { accession } \\
\text { numbers }\end{array}$ & Forward primer $\left(5^{\prime}-3\right.$ \\
\hline PIF & Pif- 177 & $\begin{array}{l}\text { Aragonite } \\
\text { formation }\end{array}$ & HE610401 & AGATTGAGGGCATAGCAT \\
\hline MSI60 & MSI60 & $\begin{array}{l}\text { Aragonite } \\
\text { formation }\end{array}$ & $\begin{array}{l}\text { No } \\
\text { accession } \\
\text { number } \\
\text { but } \\
\text { described } \\
\text { by B. } \\
\text { Marie et } \\
\text { al. } 2012\end{array}$ & TCAAGAGCAATGGTGCTA \\
\hline PERL1 & Pearlin & $\begin{array}{l}\text { Aragonite } \\
\text { formation }\end{array}$ & DQ665305 & TACCGGCTGTGTTGCTAC] \\
\hline ASP & Aspein & $\begin{array}{l}\text { Calcite } \\
\text { formation }\end{array}$ & $\begin{array}{l}\text { No } \\
\text { accession } \\
\text { number } \\
\text { but } \\
\text { described } \\
\text { by B. } \\
\text { Marie et } \\
\text { al. } 2012\end{array}$ & TGGAGGTGGAGGTATCGT \\
\hline PRISM & $\begin{array}{l}\text { Prismalin } \\
14\end{array}$ & $\begin{array}{l}\text { Calcite } \\
\text { formation }\end{array}$ & HE610393 & CCGATACTTCCCTATCTAC \\
\hline SHEM5 & Shematrin & $\begin{array}{l}\text { Calcite } \\
\text { formation }\end{array}$ & HE610376 & GTCCGAAACCAAATCGTC \\
\hline SHEM9 & Shematrin & $\begin{array}{l}\text { Calcite } \\
\text { formation }\end{array}$ & $\begin{array}{l}\text { No } \\
\text { accession } \\
\text { number } \\
\text { but } \\
\text { described } \\
\text { by B. } \\
\text { Marie et } \\
\text { al. } 2012\end{array}$ & TGGTGGCGTAAGTACAGG \\
\hline CALC1 & Nacrein & $\begin{array}{l}\text { Aragonite } \\
\text { and } \\
\text { calcite } \\
\text { formation }\end{array}$ & HQ896199 & CTCCATGCACAGACATGA \\
\hline
\end{tabular}


AQ6

AQ7

AQ8

The functioning of the pearl sac is crucial in determining surface characteristics that impact pearl quality. Detailed knowledge of the variation in gene expression of protein constructing the matrix in the pearl sac during pearl formation is an essential step towards a better understanding of pearl formation process that can help us towards the objective of improving overall pearl quality. In this study, we monitored the gene expression of eight matrix proteins in the pearl sac by using quantitative RT-PCR, according to (1) duration of culture, at 3, 6 and 9 months post-grafting operation and (2) cultured pearl surface quality traits, which were surface defects, grades and surface deposits (no nacreous deposit). Through these analyses, we obtained new insights into the determination of $P$. margaritifera pearl quality based on a molecular approach. These results allowed us to build a model based on expression of the eight genes, and to make predictions about a quality pathway. This study explores the status of functional genes, especially those regulating pearl formation, to see whether these are constant or variable according to pearl surface quality and duration of the culture period. Results of this study may contribute to the development of adapted grafting methods and aquaculture processes that will better take into account gene expression regulation pathways and the role they play in the determination of surface quality.

\section{Materials and Methods}

\section{Experimental Animal and Tissue Sampling}

Wild donor and recipient $P$. margaritifera were collected as spat in the lagoon of Mangareva (Gambier Archipelago, French Polynesia) 2 years prior grafting process. Their collection and culture are detailed in Ky et al. (2014). At this age, the dorso-ventral and antero-posterior measurements of shells average $7.85 \pm 1.2 \mathrm{~cm}$ and $7.3 \pm 1.1 \mathrm{~cm}$, respectively. A total of 600 grafts (40 donors) were performed under standard production conditions over a 2-day period, using 1.8 BU nuclei (5.45 mm diameter; Imai Seikaku Co. Ltd., Japan). All grafts were 
performed by a single expert grafter so as to avoid any grafter effect (described in Ky et al. 2015) on pearl quality traits. Details of the grafting process are given in Blay et al. (2017).

The experiment was monitored over time to evaluate changes in the gene expression of the protein matrix. Two recipient oysters were harvested for each donor after 3, 6, and 9 months of culture. Pearls and pearl sac tissue were collected at the same time. At the time of pearl harvest and in order to minimise the mixture of recipient tissues, the pearl sacs were excised from host oysters by removing the outer layers with a surgical blade until only a thin $(<0.5 \mathrm{~mm})$ layer of tissue surrounding the pearls remained, and immediately transferred into $2.0 \mathrm{ml}$ tubes with RNAlater ${ }^{\circledR}$ where they were preserved until RNA extraction (McGinty et al. 2012). A total of 80 pearl sacs were sampled every 3 months, giving a total of 240 samples over 9 months of culture.

\section{Evaluation of Pearl Surface Quality}

Once harvested, cultured pearls were cleaned by ultrasonication in soapy water with a LEO 801 laboratory cleaner (2-L capacity, $80 \mathrm{~W}$, $46 \mathrm{kHz}$ ). They were rinsed in distilled water. Some keshi (small nonnucleated nacre deposits) were also harvested but these were not graded in the present study.

Surface defects, grades and surface deposits (no nacreous deposit) of the cultured pearls were evaluated. Visible surface defects on the sampled pearls, including pits, bumps and scratches, were counted visually (without a magnifier) and each cultured pearl was then classified into one of the four categories: " 0 " (no defects), " 1 " (1 to 5 defect(s)), "2" (6 to 10 defects) and "3" (up to 10 defects). Cultured pearl grade was also determined for each pearl according to the official Tahitian classification (Journal Officiel 2001 no. 30, 26 July 2001) from the most to the least valuable quality: A, B, C, D and "Rejects" (R). Briefly, the five grades are based on surface purity and lustre, from A (cultured pearls showing no surface defects or small defects confined to less than $10 \%$ of their surface and having very good lustre) to D (cultured pearls showing many highly visible defects over more than two thirds of their surface and having poor lustre) and "Rejects" (cultured pearls that have too many defects to be graded). 
"Rejects" are discarded and ultimately destroyed. Grade descriptions are illustrated in Blay et al. (2014). Surface deposits or other surface flaws involving the nacreous layer or not were classified into five categories: 0 (no deposit), $+(10 \%$ deposit coverage $),++(25 \%$ of deposit), $+++(50 \%$ of deposit $)$ and ++++ (complete coverage by deposit). The culture pearl quality description is illustrated in Fig. 1. To ensure homogeneity in parameter assessment, all evaluations were made visually (without a jeweller's loupe) by two operators working together and cross-checking.

Fig. 1

Cultured pearl description. a Surface defect levels " 0 ": no defects, "1": 1 to 5 defect(s), "2": 6 to 10 defects and "3": more than 10 defects. b. Surface deposits (" 0 " no deposits to " ++++ " in which deposits cover the whole surface)

\section{a Surface defect}
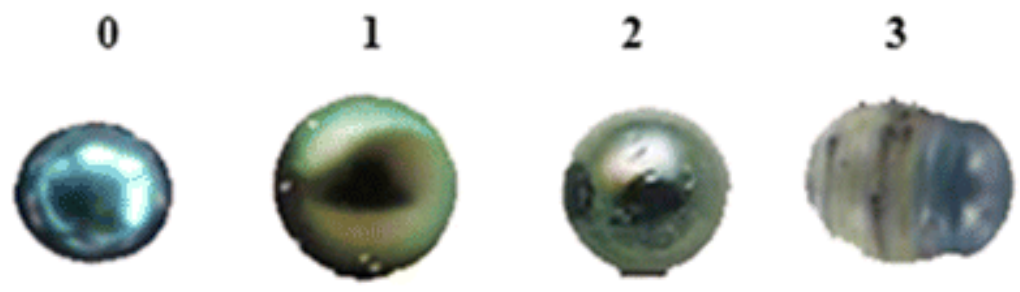

\section{b Surface deposit}
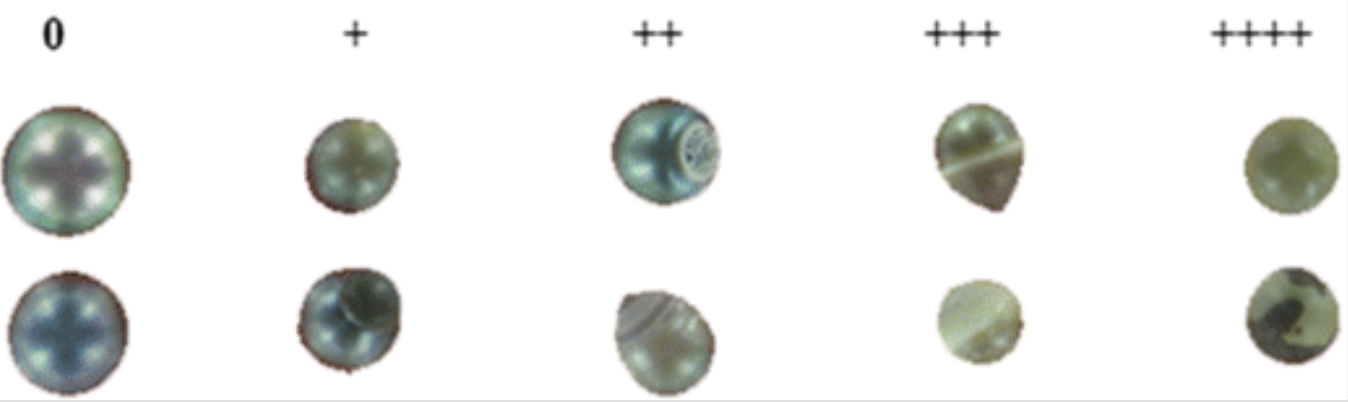

\section{Gene Expression}

We analysed pearl sac tissues to compare relative gene expression by screening three aragonite-related genes (Pif-177, MSI60, Perline), for calcite-related genes (Aspein, Shematrin, Prismalin) and one gene 
implicated in both layers (Nacrein). Primers used for amplification are given in (Table 1).

After removing the RNA later by pipetting and absorption, total cellular RNA was extracted from the individual pearl sac samples ( 80 pearl sacs sampled every 3 months, giving a total of $n=240$ pearl sac tissue samples over 9 months) using Trizol ${ }^{\circledR}$ reagent (Life Technologies) according to the manufacturer's recommendations. DNAse treatment, cDNA synthesis and Real-Time PCR amplifications were performed as described in Blay et al. (2017).

All measurements were made in duplicate and all analyses were based on the $\mathrm{Ct}$ values of the PCR products. Relative gene expression levels were calculated using the delta-delta method, normalised with two reference genes SAGE and GAPDH (Blay et al. 2017), to compare the relative expression results (Livak and Schmittgen 2001) as follows: relative expression ${ }_{\text {(target gene, sample } \mathrm{x})}=2^{\wedge}(\Delta \mathrm{Ct}$ sample, sample $\mathrm{x}-\Delta \mathrm{Ct}$ calibrator, sample $\mathrm{x})$ $=2^{-\Delta \Delta \mathrm{Ct}}$. Here, the $\Delta \mathrm{Ct}$ calibrator is the mean of the $\Delta \mathrm{Ct}$ values obtained for the tested gene.

AQ9

\section{Statistical Analysis}

Differences in pearl surface defects, grade and surface deposit rates between the three harvest times were evaluated using a $\chi^{2}$ test.

Relative Expression Analysis Normality and homoscedasticity of gene relative expression data were checked using Shapiro-Wilk and Bartlett's tests. One-way ANOVA was performed followed by Tukey's multiple comparison tests to determine expression differences of candidate marker genes among the different harvest times or in relation to the pearl quality categories considered.

Decision Tree We adapted and performed a multivariate regression tree (MRT), widely used in the domain of ecology for modelling species-environment relationships (De'Ath 2002), to evaluate the hierarchical importance of the effect of relative gene expression on the pearl quality surface pathway. Divisions in the MRT were determined by cross-validation. We performed these analyses with the 
rpart package v4.1-10 (Therneau et al. 2013) using the default parameters of the rpart function.

AQ10

All the statistical analyses were performed using $\mathrm{R}$ version 3.3.2, an environment and language for statistical computing (Team, R. C. (2015)).

\section{Results}

Of the 600 grafted oysters, 55 rejected the implanted nucleus, 26 died and 15 were lost during the course of the experiment (likely due to natural predation). A total of 464 pearls and $40 \mathrm{keshi}$ were harvested over the 12-month experimental period. Overall, we analysed a total of 211 pearls and pearl sacs over the 9 months, with 64 at 3 months, 77 at 6 months and 70 at 9 months (tissues from the last point at 12 months were of too poor a quality to be used in the analyses). The cultured pearl quality traits are described in Table 1 . Results on expression levels of the matrix protein genes are presented in the next three sections according to (1) the different stages of culture, (2) pearl quality grade and (3) the amount of pearl surface deposits, including a predictive model of pearl quality characteristics according to expression levels.

\section{Relative Gene Expression Level of Matrix Proteins at Different Stages of Pearl Culture}

Relative gene expression in the pearl sac of the panel of genes coding proteins implied in calcite or aragonite layers at three stage of the pearl formation is illustrated in Fig. 2. The relative gene expressions of PIF, MSI60 and PERL 1 were significantly much higher at month 3 of culture than at months 6 or 9 ( $p=0.006, p<0.0001$ and $p<0.0001$, respectively). For all other genes, the relative expression level was not significantly different between the different samples made over time after the graft. The temperature at harvest time was 27.0,27.0 and $25.2{ }^{\circ} \mathrm{C}$ after 3,6 and 9 month of culture, respectively.

\section{Fig. 2}

Relative expression levels of matrix proteins in the pearl sac at different stages of pearl development. Histograms in dark grey represent data for 
all pearls at 3 months and histograms in light grey represent data at 9 months. $Y$ axes are in the logarithmic scale. Error bars indicate standard deviations. Statistical differences between the phenotypes are indicated by asterisks: $*$ for $0.05<p<0.005,{ }^{* *}$ for $0.005<p<0.0005, * * *$ for $p<$ 0.0005

AQ11

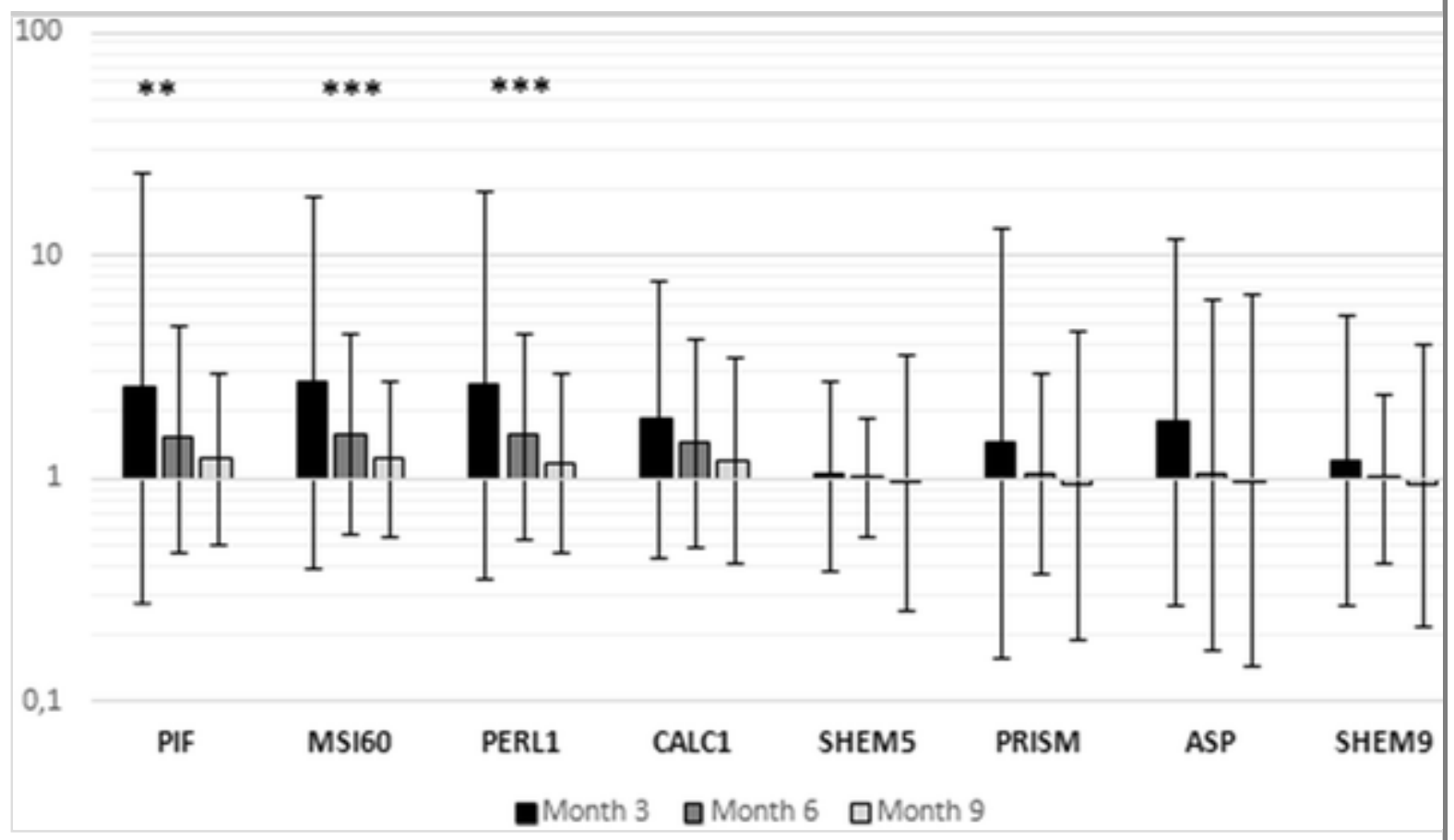

Analysing kinetics data over the 9 months following the graft, we did not find any preferential harvest time when focusing on changes in surface defects ( $\chi^{2}$ test, $\left.p=0.590\right)$. After 3 months of culture, the pearl surface defects were distributed as follows: " 0 " $4.7 \%, n=3$; " 1 " $31.2 \%$, $n=20$; " 2 " $25.0 \%, n=16$ and " 3 " $39.1 \%, n=25$. After 9 months of culture, the distribution was similar: " 0 " $4.3 \%, n=3$; " 1 " $40.0 \%, n=28$; "2" $22.9 \%, n=16$ and " 3 " $32.8 \%, n=23$ (Table 2).

\section{Table 2}

Cultured pearl quality traits from the experimental graft. Percentages of cultured brackets) at each harvest time (3,6 and 9 months of culture) among the following (1) Surface defect classes (" $0 "=0$ defects, " $1 "=1-5$ defects, " $2 "=6-10$, and " Classification grade (A, B, C, D and reject: R); and (3) Surface deposit ("0", “++++" small deposits to complete coverage) 


\begin{tabular}{|l|c|c|c|c|c|c|c|c|c|c|c|}
\hline & \multicolumn{9}{|c|}{ Surface defect } & \multicolumn{5}{c|}{ Grade } & \multicolumn{3}{c|}{ Su } \\
\hline & $\mathbf{0}$ & $\mathbf{1}$ & $\mathbf{2}$ & $\mathbf{3}$ & $\mathbf{A}$ & $\mathbf{B}$ & $\mathbf{C}$ & $\mathbf{D}$ & $\mathbf{R}$ & $\mathbf{0}$ & + \\
\hline $\begin{array}{l}\text { Month } \\
3\end{array}$ & 4.7 & 31.2 & 25.0 & 39.1 & 11.0 & 14.1 & 18.7 & 18.7 & 37.5 & 46.9 & 15.1 \\
\hline & $(3)$ & $(20)$ & $(16)$ & $(25)$ & $(7)$ & $(9)$ & $(12)$ & $(12)$ & $(24)$ & $(30)$ & $(10$ \\
\hline $\begin{array}{l}\text { Month } \\
6\end{array}$ & 2.6 & 48.0 & 16.9 & 32.5 & 11.7 & 35.0 & 20.8 & 18.2 & 14.3 & 76.6 & 10. \\
\hline & $(2)$ & $(37)$ & $(13)$ & $(25)$ & $(9)$ & $(27)$ & $(16)$ & $(14)$ & $(11)$ & $(59)$ & $(8)$ \\
\hline $\begin{array}{l}\text { Month } \\
9\end{array}$ & 4.3 & 40.0 & 22.9 & 32.8 & 10.0 & 20.0 & 42.9 & 17.1 & 10.0 & 82.9 & 10.1 \\
\hline & $(3)$ & $(28)$ & $(16)$ & $(23)$ & $(7)$ & $(14)$ & $(30)$ & $(12)$ & $(7)$ & $(58)$ & $(7)$ \\
\hline$<$ & & & & & & & & & & & $>$ \\
\hline
\end{tabular}

Data analysis showed a highly significant difference in pearl surface deposits between harvest times $\left(\chi^{2}\right.$ test, $\left.p<0.0001\right)$. After 3 months, pearls possessed significantly more surface deposits than at 6 and 9 month pearls. For example, at the 3 month sampling, $18.8 \%$ of the pearls were "++++" while only $5.2 \%$ and $2.8 \%$ fell into the "++++" category at 6 and 9 months, respectively. In the 3-month sample, pearls without deposits accounted for $46.9 \%$ of the collection, against 76.6 and $82.9 \%$ after 6 and 9 months of culture, respectively (Table 2).

There were also significantly more reject among the pearls harvested at 3 months after grafting than among those collected after 6 and

9 months. After 3 months of culture, $37.5 \%$ of the pearl fell into the "R" category while only 14.3 and $10.0 \%$ were classified as "R" after 6 and 9 months of culture, respectively (Table 1).

\section{Impact of Biomineralisation Gene Expression Level on Pearl Surface Quality}

Among the eight candidate genes studied in the pearl sac at month 3, the expressions of four of them were significantly different in pearl sac between the surface defect categories (Online Resource 1). PIF, MSI60 and PERL1 gene expression levels were significantly 5.2, 3.4, 4.2 times higher, respectively for pearls with less defect ( 0 to 9 defects), in comparison to pearls having more than 10 defects, which had a fold change inferior to $0.6(p<0.0001)$. Inversely, SHEM5 showed significantly greater expression in pearls having more than 10 defects, 
with a 3.0-fold change compared with pearls having 0 to $5 \operatorname{defect}(\mathrm{s})$, which had a 0.4 -fold change ( $p=0.003$ ). At month 6 , the relative expression of gene encoding matrix protein of Aspein and Shematrin families in pearl sac were significantly different between the categories of surface defect. ASP and SHEM9 showed significantly higher fold change 9.0 and 2.5 , respectively for pearls with more than 10 defects compared to other pearls which had fold change inferior at 0.5 for ASP and inferior at 1 for SHEM9 ( $p<0.001$ and $p=0.024$ respectively). After 9 months of culture, only the relative expressions of gene encoding matrix protein of Aspein family were significantly different between the surface defect categories. ASP gene expression level in pearl sac showed significantly higher relative expression levels for pearls with more than 10 defects (fold change $=4.7$ ) compared to other pearls (fold change $<1)(p=0.001)$.

After 3 month of culture, only CALC1 encoding a nacrein protein matrix was not significantly different among the different level of surface deposit on the pearls. In fact, the three genes encoding aragonite protein PIF, MSI60 and PERL1 showed higher relative gene expression level in pearl "without deposit" (fold change $=6.0,4.0,4.7$, respectively), compared to " ++++ " pearl category (fold change $=0.1$, $0.6,0.4$, respectively) ( $p<0.0001, p=0.001$ and $p=0.0001$, respectively). Inversely, SHEM5, PRISM, ASP and SHEM9 encoding protein playing a role in calcite formation, had higher expression levels for pearls with overall deposit (fold change $=7.9,40.5,13.3,20.1$, respectively) than pearls "without deposit" and pearls with "+" low deposit (fold change < 1) (Online Resource 2). At month 6, three genes encoding aragonite protein, PIF, MSI60 and PERL1 were significantly different according to the deposit level on pearls ( $p=0.004, p=0.006, p$ $=0.006$, respectively). Data analysis showed a lower expression of these genes for the pearls in the "++++" category. Inversely, pearls with high surface deposit "++++" showed higher relative expression level of gene encoding protein taking part in calcite formation such as PRISM ( $p=$ $0.001)$, ASP $(p<0.0001)$ and SHEM9 $(p=0.002)$ (fold change $=175.1$, $698.3,122.4$, respectively) than pearls "without deposit" (fold change $<$ 1). After 9 month of culture rearing, PRISM, ASP and SHEM9 expression levels were significantly different among the levels of deposit on the pearls ( $p<0.0001, p=0.0002, p=0.0001$, respectively). 
PRISM, ASP and SHEM9 had higher expression levels for pearls with deposit ("+" to "++++") (mean fold change $=68.3,221.0,33.5$, respectively) than pearls "without deposit" (fold change $<0.6)($ Online Resource 2).

After 3 months of culture, only CALC1 and MSI60 were not significantly different among the different pearl grades. In fact, two genes encoding aragonite proteins, PIF and PERL1, had higher relative gene expression in pearl sacs of $\mathrm{A}, \mathrm{B}$ and $\mathrm{C}$ grade pearls (fold change $>$ 4) compared to pearl classified as "R" (rejects) (fold change $=0.7$ and 1.1 , respectively) ( $p<0.0001$ and $p=0.002$, respectively). Inversely, SHEM 5, PRISM, ASP and SHEM9, which encode proteins playing a role in calcite formation, had higher gene expression levels for reject pearls (fold change $=3.0,7.5,5.4,5.2$, respectively) than for grade "A" pearls (fold change $<0.4$ ) (Fig. 3).

Fig. 3

Relative expression of 8 biomineralisation genes in the pearl sac of $P$. margaritifera: a at 3 months, b 6 months and c 9 months. Histograms in dark grey show data for " $A$ " grade pearls and light grey histograms show data for the "R" grade pearls (rejects). Y axes are in the logarithmic scale. Error bars indicate standard deviations. Statistical differences between the phenotypes are indicated by asterisks: * for $0.05<p<0.005, * *$ for 0.005 $<p<0.0005, * * *$ for $p<0.0005$ 


\section{a 3 months}

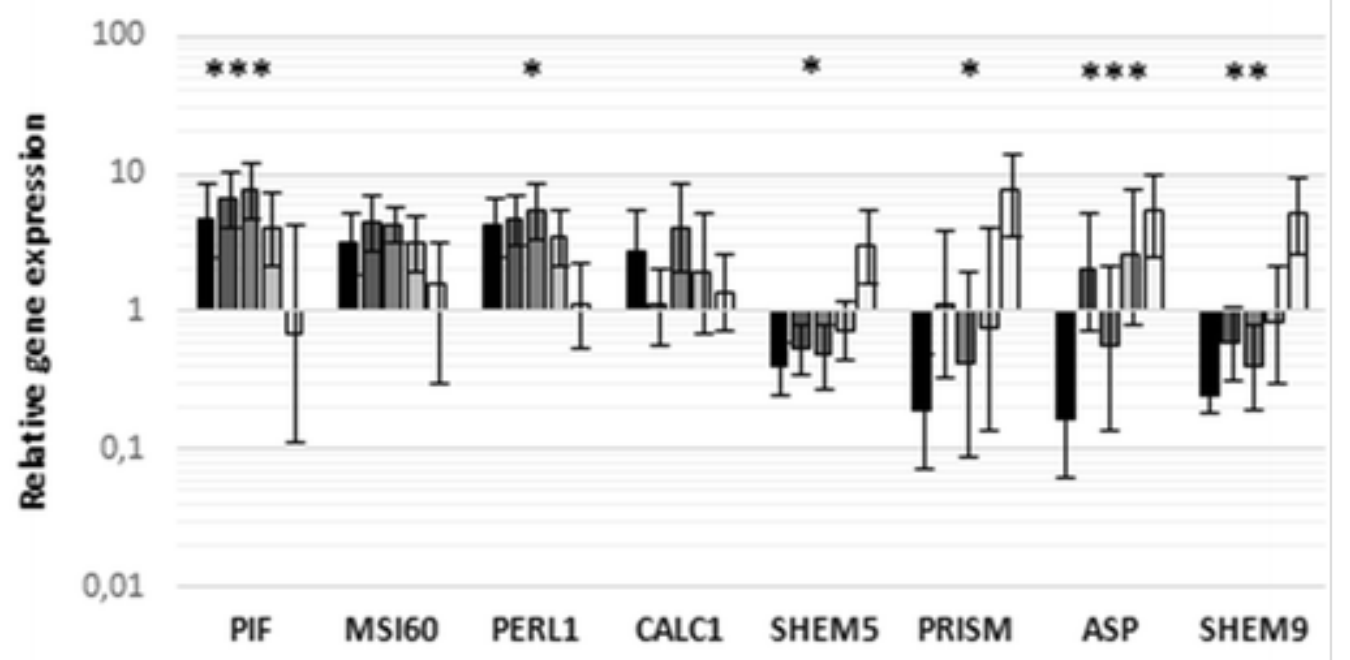

\section{b 6 months}

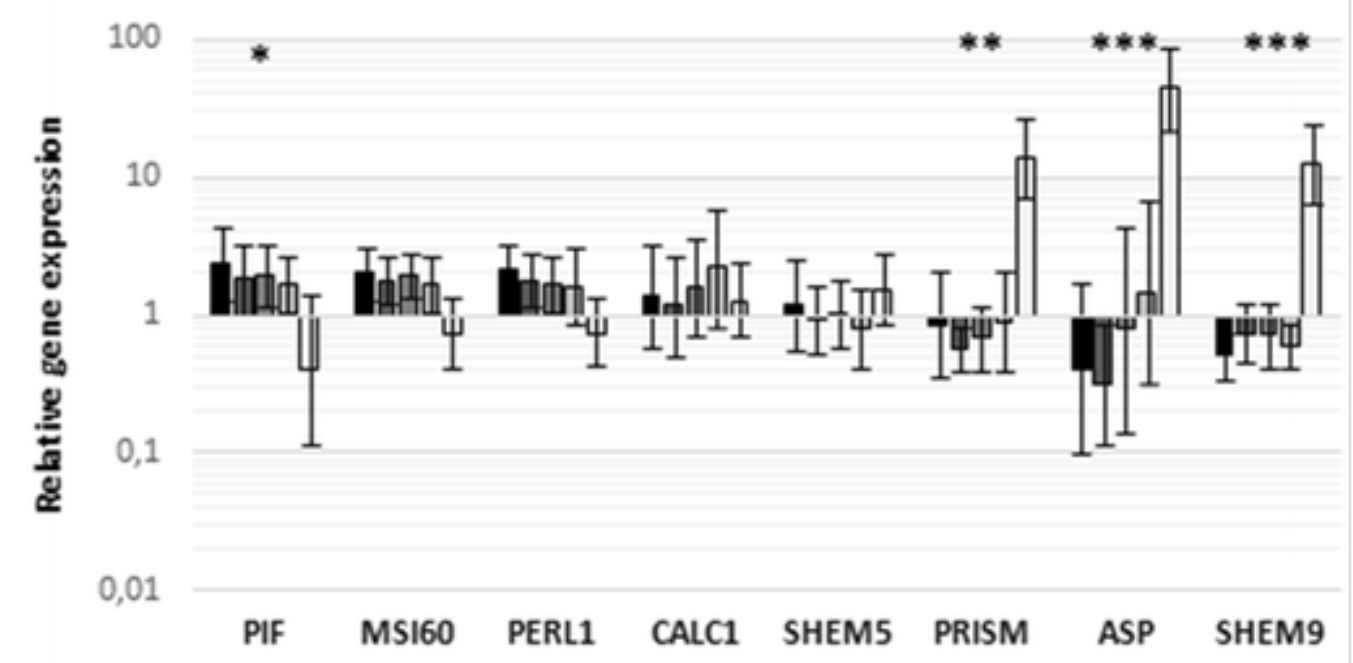

\section{c 9 months}

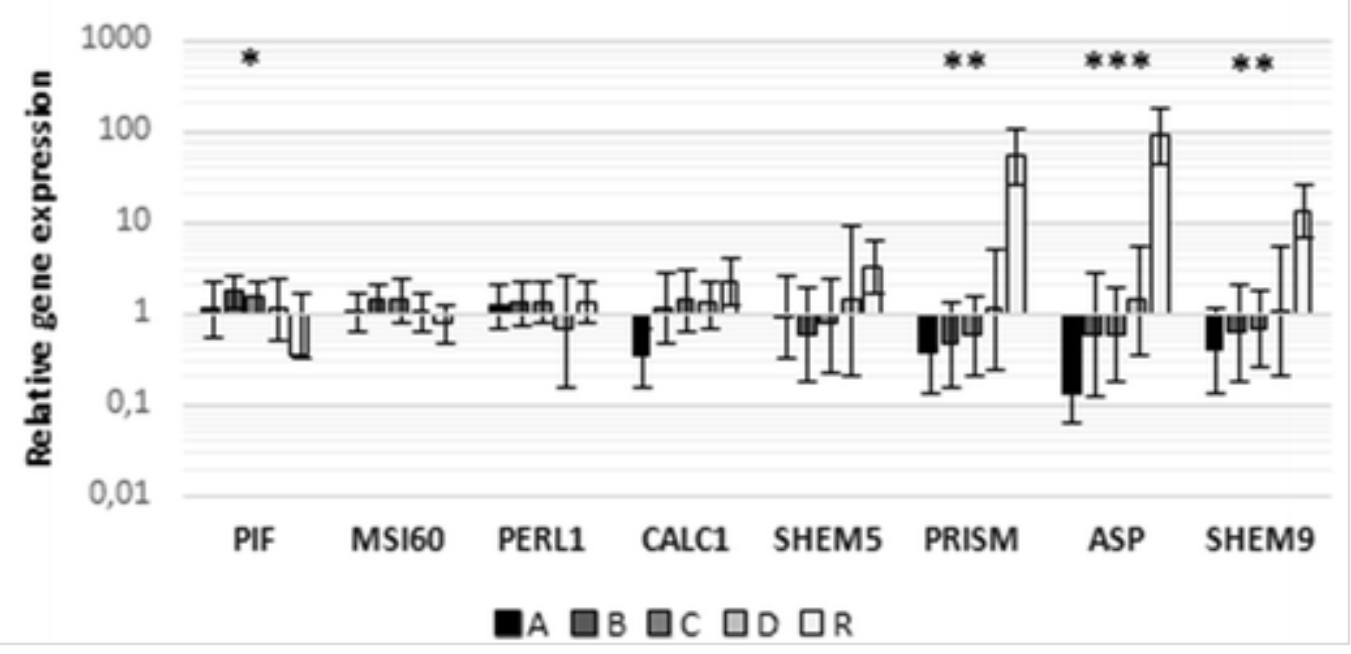

At 6 months, $P I F$ expressions were significantly different between the grade categories of the pearls $(p=0.01)$. Data analysis showed lower 
expression of this gene for "R" pearls. PRISM, ASP and SHEM9 showed significantly higher fold changes $(13.7,44.4,12.5$, respectively) for reject pearls compared to other pearls, which had fold changes $<1$ for PRISM and SHEM9 and $<1.5$ for ASP ( $p=0.02, p<0.001$ and $p$ $=0.0006$, respectively).

After 9 months of culture, PRISM, ASP and SHEM9 expression levels were significantly different among the pearl grades $(p=0.003, p=$ 0.0001, $p=0.005$, respectively). PRISM, ASP and SHEM9 had higher expression levels for reject pearls (fold change $=53.3,89.9,13.5$, respectively) than for A, B and C pearls (fold change < 1) (Fig. 3).

\section{Predictive Model of Cultured Pearl Surface Deposits}

To determine the major gene expression level explaining, and thus affecting, pearl surface quality, we performed three multivariate regression trees, as shown in Fig. 4. From the MRT model obtained for surface deposit, it appeared that, among the eight input variables, the most important factors/predictors were relative expression levels of four genes: SHEM9, ASP, CALC1 and PIF. The first regression tree split is based on the relative gene expression level of SHEM9. When this level is higher than 9.571, following the MRT to the left, a second split then occurs based on the relative gene expression level of PIF. Samples showing PIF expression level greater or equal to 0.314 are on "+++" deposit pathways ( $50 \%$ of the total "+++" pearls harvested), whereas samples showing a level lower than this critical value are on overall calcite pearl pathways (67\% of "++++" pearls harvested). If the expression level of SHEM9 is lower than 9.571 then, following the regression tree to the right, a second split is based on the relative gene expression level of ASP. Samples showing an ASP expression level lower than 6.958 are on the "without deposit" pathway (93\% of the total pearls without deposits harvested), whereas samples showing an expression level greater or equal to 6.958 are on pathways with more surface defects. Finally, the third and the last split of the regression three is based on the CALCl expression level, and differentiates samples without deposit and samples with "+" low deposit.

\section{Fig. 4}


Multivariate regression trees of pearl quality categories $(n=211)$. Candidate predictor/explanatory variables are the relative expression ratio of the eight potential marker genes, and the response variables are a the four sub-clusters of surface defect without to more than 10 defect on surface pearl, $\mathbf{b}$ the five sub-clusters of surface deposit, without to overall deposit on surface pearl, and $\mathbf{c}$ the five sub-clusters of grade classification, "A" to "R" (reject) pearls 


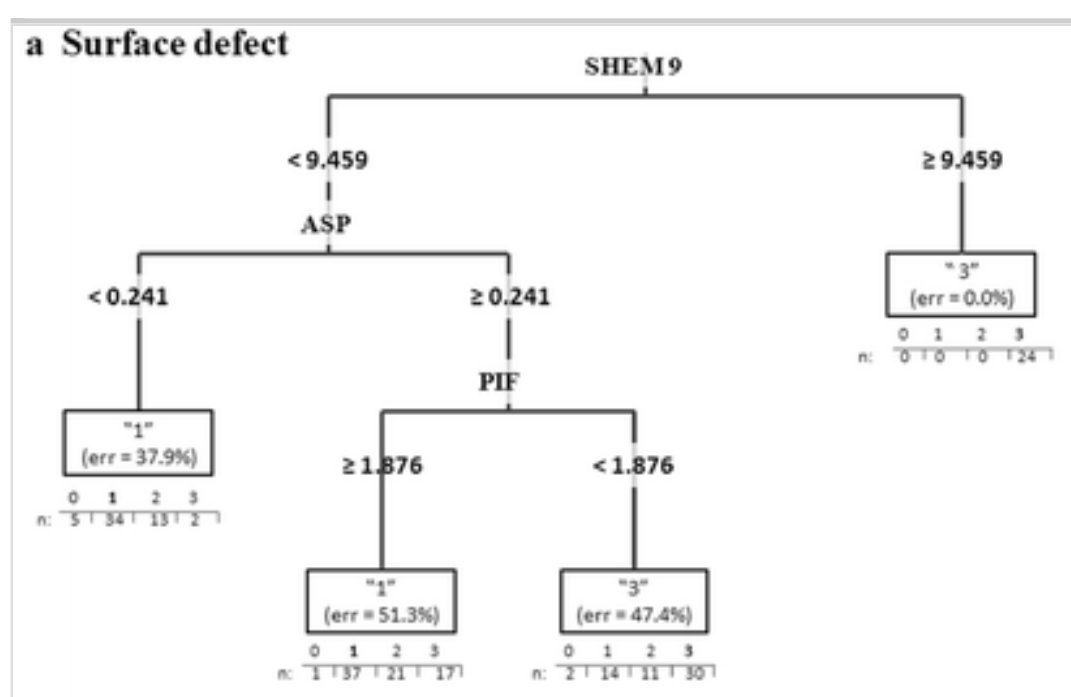

b Surface deposit

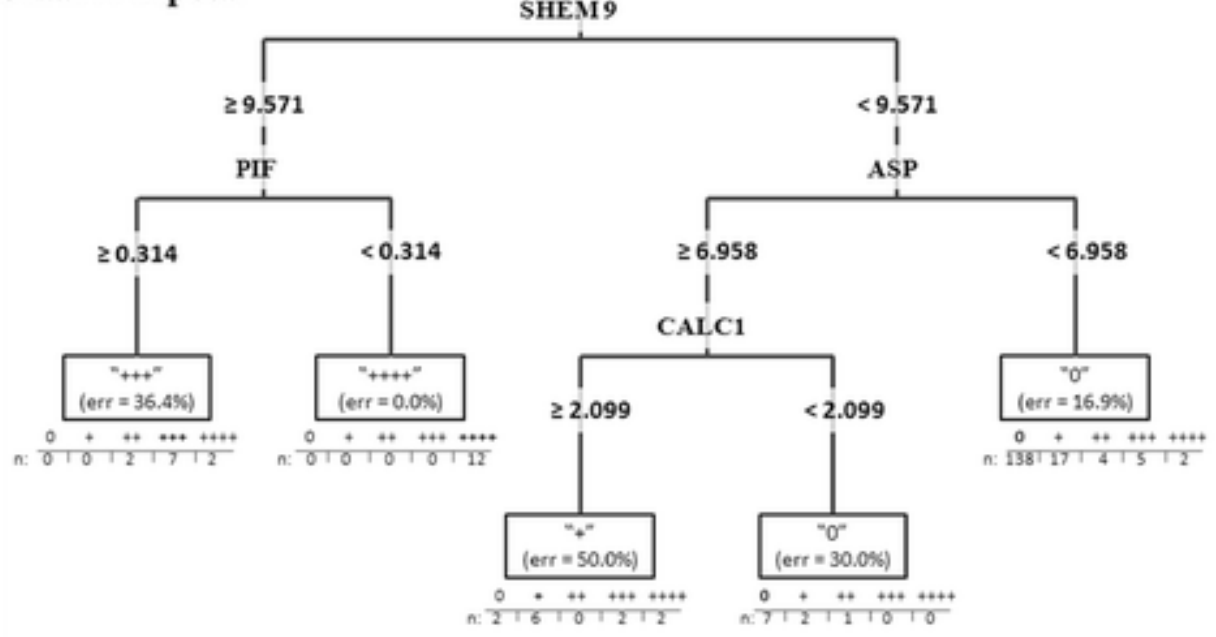

c Grade

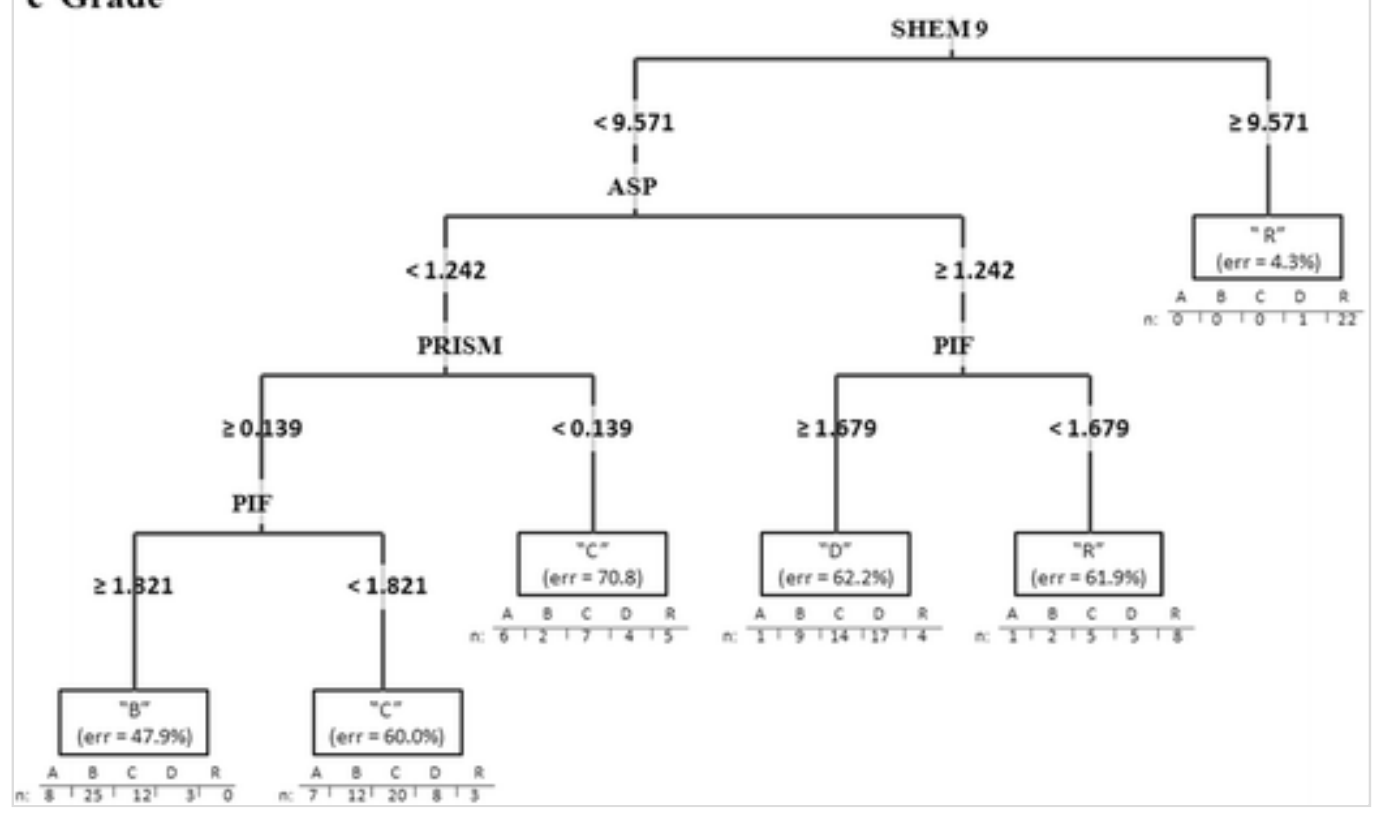

From the MRT model obtained for surface defects, it appeared that the most important factors/predictors were relative expression levels of 3

http://eproofing.springer.com/journals_v2/printpage.php?token=FQrWiRjlm3CYq5f6... 26/03/2018 
genes: SHEM9, ASP and PIF. The first regression tree split is based on the relative gene expression level of SHEM9. When this level is higher than 9.459, following the MRT to the right, samples are on pathways of more than 10 defects with a $0 \%$ error. If the expression level were $<$ 9.459, a second split then occurs based on the relative gene expression level of $A S P$. Samples showing ASP expression levels lower than 0.241 are on " 1 " surface defect (less than 5 defects) pathways.

From the MRT model obtained for classification grade, it appeared that the most important factors/predictors were relative expression levels of 4 genes: SHEM9, ASP, PRISM and PIF. The first regression tree split is based on the relative gene expression level of SHEM9. When this level is higher or equal than 9.571 , following the MRT to the right, samples are on reject pathways with a $4.3 \%$ error. If the expression level is lower than 9.571, subsequent splits occur based on the relative gene expression level of ASP and then PRISM and PIF. Samples showing an $A S P$ expression level lower than 1.242 are on "B" and " $C$ " grade pathways while with an $A S P$ expression level greater or equal to 1.242, samples are on D or R grade pathways. Thus, following these MRT model of $P$. margaritifera pearl surface quality, we can associate pearls with the particular pathways by analysing the expression level of three common genes (i.e. SHEM9, ASP and PIF), which relate to surface defect, surface deposit and grade.

\section{Discussion}

\section{Biogenesis of the Quality of Cultured Pearl Surfaces}

The pearl oyster shell typically consists of an outermost organic layer known as the periostracum, and calcium carbonate oriented in two distinct microlaminates: the outer calcite prismatic layer and the inner aragonite nacreous layer (Zhu et al. 2015). In previous studies, which essentially investigate the first day after the graft (less than 80 days monitored), the first deposit on the nucleus was aragonitic (Cuif et al. 2008; Liu et al. 2012) or calcitic (Ma et al. 2007) prismatic layer and this was followed by the nacreous layer, which started to develop on top of the prismatic layer. One study described two consecutive stages in the whole process of pearl formation (for the first 35 days), starting with an irregular calcium carbonate deposition on the bare nucleus (Liu 
et al. 2012). Calcium carbonate deposition then becomes increasingly regular until the mature nacreous layer has been formed on the nucleus.

In our study, the level of surface deposit on pearls decreased over the culture period. At 3 months, 54\% of culture pearls harvested had some deposits vs. $17 \%$ at 9 months. Concerning grade classification results (which relies on lustre and surface defects), we showed that the rate of rejects declines over time, with $37.5 \%$ at the 3 -month harvest vs. $10 \%$ at the 9-month harvest. Meanwhile, pearl surface defects, such as pits, bumps and scratches, had a steady proportion after 3, 6 or 9 months of culture (about 35\%). Our study suggests that prismatic layer formation takes place during the first 3 months after nucleus implantation and that aragonite layer formation had not yet started for all pearls by this point. Surface defects appeared after the grafting procedure and remained throughout the culture period, while surface deposits appeared after grafting procedure and could then be covered over during the by a nacreous layer. Surface defects were thus formed early and could be the consequence of haemocyte accumulation after the grafting. A previous study showed that accumulation of haemocytes during pearl sac development may result in malformation of the pearl sac, which is likely to result in reduced pearl quality (Kishore and Southgate 2014), and according to our results could not be corrected during the culture period. To avoid surface defects on the pearl and improve pearl quality, careful graft preparation and surgery are essential parameters (Southgate and Lucas-2011). One of our previous study showed that the grade is correlated with pearl nacre thickness, with grade A pearls having the thickest and heaviest nacre on average, and thickness increasing over time of culture (Blay et al. 2014). The thickness of nacreous deposit is essential to improve the quality of the pearl surface. After examining the evolution of the pearl surface quality over the culture period, it is essential to understand the role of the matrix proteins in the pearl formation.

\section{The Role of the Matrix Proteins in the Formation of Pearl Surface Quality}

The mechanisms of the matrix proteins, which are fundamental for pearl quality formation, are not well known. The role of these proteins is a 
crucial question that still needs to be elucidated in pearl oyster because of its important implications for pearl quality and, therefore, the success of the pearl oyster aquaculture. Here, we selected eight genes as potential markers of the quality pearl pathway based on the literature (Marie et al. 2012; Joubert et al. 2010). These genes have already been shown to play a role in shell formation through the biomineralisation process (Suzuki et al. 2009,2013; Miyamoto et al. 2005, 2013;

Montagnani et al. 2011; Huang et al. 2013; Shi et al. 2013; Suzuki and Nagasawa 2013).

AQ12

AQ13

AQ14

This study cannot answer the question of what kinds of factors affect the gene expression patterns of individual pearl sacs, but we studied the evolution of gene expression in pearl sacs over the pearl culture period and the impact of this expression on pearl quality surface. Through a multivariate regression tree, we identified three genes whose expression level correlated with the pearl surface quality pathway and which can thus be considered as major quality determinants. The three genes implicated in the surface quality pathway are SHEM9, ASP and PIF. Interestingly, the relative gene expression level of SHEM9 $(<9.5)$ and $A S P(<1)$ appear crucial in lowering surface deposits, surface defects and creating a pathway that will lead to a good grade. The low expression of these two genes can inhibit surface deposits and lead to top quality pearls. These findings suggest that inhibition of the prismatic layer in pearl formation should decrease the proportion of low quality pearls by diminishing the presence of calcite and pearl surface defects, which increases the grade classification. An RNAi (RNA interference) experiment could be performed using double-stranded RNA (dsRNA) of a calcitic gene by injecting it into the pearl sac and examining the pearl surface quality. This method would be useful to investigate functions of genes and their impact on cultured pearl surface quality. This technique has been widely used to investigate functions of uncharacterized genes (Fire et al. 1998) and has been effectively applied in bivalves (Suzuki et al. 2009; Fang et al. 2011; Yan et al. 2014; Funabara et al. 2014; Owens and Malham 2015). 
Moreover, our results indicate that in the first 6 months of the pearl formation, the three "aragonitic-layer-forming" genes were significantly less expressed for the pearls wholly covered by surface deposits. During the first 3 months of the pearl culture, the three aragonitic-layerforming genes were also significantly less expressed for pearls with more than six surface defects. Moreover, the levels of expression for these aragonitic-layer-forming genes decreased with time of culture. In the later periods (after 3 months), their expression levels were relatively low. Studies have observed that MSI60, a matrix protein in the nacreous layer, has several characteristic domains that constitute the baseline of the nacreous layer (Sudo et al. 1997; Inoue et al. 2011a, b). Pif, an acidic protein isolated from the nacreous layer, has been reported to regulate the formation of this layer (Suzuki et al. 2009). Pearlin, which is mainly present in the nacreous layer, induces formation of aragonite crystals when Pearlin is fixed to the substrate (Suzuki and Nagasawa 2013). These results show that the three genes contributing to the formation of the aragonitic layer are high expressed at the beginning of pearl biogenesis. In Blay et al. (2017), we showed that nacreous deposition is not linear during the pearl formation process and that the highest deposition rate was in the first 3 months. After 6 months, almost $70 \%$ of the final nacre thickness had already been reached. For early stage aragonite formed in the 15 days after grafting, the deposition did not appear to be accurately controlled by the organic matrix (Liu et al. 2012). Two studies on $P$. margaritifera showed that the pearl sac development required between 12 (Cochennec-Laureau et al. 2010) and 14 (Kishore and Southgate 2014) days, which is a shorter period than that required in P. maxima (Scoones 1996) or 65 days in $P$. fucata (Wada 1968; Achari 1982). All of these results indicate the importance of the earliest stages of the culture process.

AQ15

Another interesting finding was the relatively high level of PRISM, ASP and SHEM9 expression in cases of complete deposit coverage of the pearl, reject-grade pearls or high levels of surface defects during pearl formation and the relatively low expression of these genes in cases of pearl without deposits or surface defects and belonging to grades A or B. Shematrin is a family of glycine-rich shell matrix proteins known to be present in the prismatic microstructure of several pearl oyster species 
(Gardner et al. 2011). Shematrins are framework proteins facilitating calcification of the prismatic microstructure (Yano et al. 2006). Aspein is involved in specific calcite formation in the prismatic layer of the shell and works on crystal formation in prisms (Tsukamoto et al. 2004; Takeuchi et al. 2008; Gao et al. 2016). Aspein would accelerate calcite formation (Takeuchi et al. 2008). In a similar way to Aspein, Prismalin14 is responsible for the prismatic layer of the shell but may act as a framework protein that mediates chitin and calcium carbonate crystals using its acidic and chitin-binding regions (Suzuki et al. 2004-; Suzuki and Nagasawa 2007). These findings suggest when the pearl had surface deposits or defects, Shematrin and Aspein and Prismalin 14 were expressed throughout the pearl culture period, but when the pearls were formed is without surface defects, these "prismatic-layer-forming" genes were not expressed. These results also suggest that surface deposits corresponded to a prismatic layer.

AQ16

For the first time, cultured pearl biogenesis was followed over the first 9 months of $P$. margaritifera pearl culture examining both pearl phenotype and pearl sac molecular parameters. Results showed that the first 3 months of pearl biogenesis in P. margaritifera is primordial in determining pearl surface quality. In addition, three genes encoding proteins involved in the biomineralisation process (SHEM9, ASP and $P I F)$ were implicated in the surface quality signature of the cultured pearl. The findings provide a basis for future research towards developing improved pearl culture practice and pearl quality.

\section{Acknowledgements}

The authors would especially like to thank the host sites: SCA Regahiga Pearls (Mangareva island, Gambier archipelago, French Polynesia) and Gauguin's pearl farm (Rangiroa atoll, Tuamotu archipelago, French Polynesia) for their generous support. The authors are indebted to $\mathrm{S}$. Parrad and S. Nakasai for their helpful assistance. C. Blay was jointed funded by an Ifremer PhD grant, with a support from the "Direction des ressources marines" and CRIOBE EPHE.

Funding Information 
This study was supported by grants from the "Direction des ressources marines et Minières", through the TripaGEN project (2015-2017).

Compliance with Ethical Standards

Competing Interests The authors declare that they have no competing interests.

\section{Electronic supplementary material}

\section{ESM 1 ESM 2}

(DOC $50 \mathrm{~kb})($ DOC $208 \mathrm{~kb})$

\section{References}

AQ17

Achari GPK (1982) Project profile of pearl culture. Seaf Export J $14: 9-11$

Addadi L, Weiner S (1985) Interactions between acidic proteins and crystals: stereochemical requirements in biomineralisation. Proc Natl Acad Sci U S A 82:4110-4114

Arnaud-Haond S, Goyard E, Vonau V, Herbaut C, Prou J, Saulnier D (2007) Pearl formation: persistence of the graft during the entire process of biomineralization. Mar Biotechnol 9(1):113-116

Belcher AM, Wu XH, Christensen RJ, Hansma PK, Stucky GD, Morse DE (1996) Control of crystal phase switching and orientation by soluble mollusc-shell proteins. Nature 381:56-58

Blay C, Sham-Koua M, Vonau V, Tetumu R, Cabral P, Ky CL (2014) Influence of nacre deposition rate on cultured pearl grade and colour in the black-lipped pearl oyster Pinctada margaritifera using farmed donor families. Aquac Int 22(2):937-953 
Blay C, Planes S, Ky CL (2017) Donor and recipient contribution to phenotypic traits and the expression of biomineralisation genes in the pearl oyster model Pinctada margaritifera. Scientific Report, 7 (1), 2696. https://doi.org/10.1038/s41598-017-02457-x AQ18

Cochennec-Laureau N, Montagnani C, Saulnier D, Fougerouse A, Levy P, Lo C (2010) A histological examination of grafting success in pearl oyster Pinctada margaritifera in French Polynesia. Aquat Living Resour 23(1):131-140

Cuif JP, Ball AP, Dauphin Y, Farre B, Nouet J, Perez-Huerta A, Salome' M, Williams CT (2008) Structural, mineralogical and biochemical diversity in the lower part of the pearl layer of cultivated seawater pearls from Polynesia. Microsc Microanal $14: 405-417$

De'Ath G (2002) Multivariate regression trees: a new technique for modeling species-environnement relationships. Ecology 83:1105 $-1117$

Ellis S, Haws M (1999) Producing pearls using the black-lip pearl oyster (Pinctada margaritifera). Aquafarmer Information Sheet, 141, $8 \mathrm{pp}$ AQ19

Falini G, Albeck S, Weiner S, Addadi L (1996) Control of aragonite or calcite polymorphism by mollusc shell macromolecules. Science 27:167-169

Fang D, Xu G, Hu Y, Pan C, Xie L, Zhang R (2011) Identification of genes directly involved in shell formation and their functions in pearl oyster, Pinctada fucata. PLoS One 6:e21860

Fire A, Xu SQ, Montgomery MK, Kostas SA, Driver SE, Mello CC (1998) Potent and specific genetic interference by double-stranded RNA in Caenorhabditis elegans. Nature 391:806-811 
Funabara D, Ohmori F, Kinoshita S, Koyama H, Mizutani S, Ota A, ..., Kanoh S (2014) Novel genes participating in the formation of prismatic and nacreous layers in the pearl oyster as revealed by their tissue distribution and RNA interference knockdown. PLoS One 9 (1): 884706

Gao J, Chen Y, Yang Y, Liang J, Xie J, Liu J, ..., Zhang R (2016) The transcription factor Pf-POU3F4 regulates expression of the matrix protein genes Aspein and Prismalin-14 in pearl oyster (Pinctada fucata). FEBS J 283(10):1962-1978

Gardner LD, Mills D, Wiegand A, Leavesley D, Elizur A (2011) Spatial analysis of biomineralisation associated gene expression from the mantle organ of the pearl oyster Pinctada maxima. BMC Genomics 12(1):455

Huang XD, Zhao M, Liu WG, Guan YY, Shi Y, Wang Q, ..., He MX (2013) Gigabase-scale transcriptome analysis on four species of pearl oysters. Mar Biotechnol 15(3):253-264

Inoue $\mathrm{N}$, Ishibashi R, Ishikawa $\mathrm{T}$, Atsumi T, Aoki H, Komaru A (2010) Gene expression patterns and pearl formation in the Japanese pearl oyster (Pinctada fucata): a comparison of gene expression patterns between the pearl sac and mantle tissues. Aquaculture 308:S68-S74

Inoue N, Ishibashi R, Ishikawa T, Atsumi T, Aoki H, Komaru A (2011a) Can the quality of pearls from the Japanese pearl oyster (Pinctada fucata) be explained by the gene expression patterns of the major shell matrix proteins in the pearl sac? Mar Biotechnol 13 (1):48-55

Inoue N, Ishibashi R, Ishikawa T, Atsumi T, Aoki H, Komaru A (2011b) Gene expression patterns in the outer mantle epithelial cells associated with pearl sac formation. Mar Biotechnol 13:474-483

Joubert C, Piquemal D, Marie B, Manchon L, Pierrat F, ZanellaCléon I, ..., Montagnani C (2010) Transcriptome and proteome 
analysis of Pinctada margaritifera calcifying mantle and shell: focus on biomineralisation. BMC Genomics 11:613-626

Kishore P, Southgate PC (2014) A detailed description of pearl-sac development in the black-lip pearl oyster, Pinctada margaritifera (Linnaeus 1758). Aquaculture Research 47 (7) 2215-2226 AQ20

Ky CL, Blay C, Sham-Koua M, Vanaa V, Lo C, Cabral P (2013) Family effect on cultured pearl quality in black-lipped pearl oyster Pinctada margaritifera and insights for genetic improvement. Aquat Living Resour 26:133-145

Ky CL, Molinari N, Moe E, Pommier S (2014) Impact of season and grafter skill on nucleus retention and pearl oyster mortality rate in Pinctada margaritifera aquaculture. Aquac Int 22(5):1689-1701

Ky CL, Nakasai S, Molinari N, Devaux D (2015) Influence of grafter skill and season on cultured pearl shape, circles and rejects in Pinctada margaritifera aquaculture in Mangareva lagoon. Aquaculture 435:361-370

Ky CL, Okura R, Nakasai S, Devaux D (2016) Quality trait signature at archipelago scale of the cultured pearls produced by the blacklipped pearl oyster (Pinctada margaritifera Var. cumingi) in French Polynesia. J Shellfish Res 35(4):827-835

Levi Y, Albeck S, Brack A, Weiner S, Addadi L (1998) Control over aragonite crystal nucleation and growth: an in vitro study of biomineralisation. Chem Eur J 4:389-396

Liu X, Li J, Xiang L, Sun J, Zheng G, Zhang G, Zhang R (2012) The role of matrix proteins in the control of nacreous layer deposition during pearl formation. Proc R Soc Lond B Biol Sci 279(1730):1000 $-1007$ 
Lowenstam HA, Weiner S (1989) On Biomineralisation. Oxford University Press, Oxford

Ma H, Zhang B, Lee IS, Qin Z, Tong Z, Qiu S (2007) Aragonite observed in the prismatic layer of seawater cultured pearls. Front Mater Sci Chin 1:326-329

Marie B, Joubert C, Tayalé A, Zanella-Cléon I, Belliard C, Piquemal D, ..., Montagnani C (2012) Different secretory repertoires control the biomineralisation processes of prism and nacre deposition of the pearl oyster shell. Proc Natl Acad Sci 109:20986-20991

Marin F, Luquet G, Marie B, Medakovic D (2007) Molluscan shell proteins: primary structure, origin, and evolution. Curr Top Dev Biol 80:209-276

McGinty EL, Zenger KR, Jones DB, Jerry DR (2012) Transcriptome analysis of biomineralisation-related genes within the pearl sac: host and donor oyster contribution. Mar Genomics 5:27-33

Miyamoto H, Miyashita T, Okushima M, Nakano S, Morita T, Matsushiro A (1996) A carbonic anhydrase from the nacreous layer in oyster pearls. Proc Natl Acad Sci U S A 93:9657-9660

Miyamoto H, Miyoshi F, Kohno J (2005) The carbonic anhydrase domain protein nacrein is expressed in the epithelial cells of the mantle and acts as a negative regulator in calcification in the mollusk Pinctada fucata. Zool Sci 22:311-315

Miyamoto H, Endo H, Hashimoto N, Isowa Y, Kinoshita S, Kotaki $T, \ldots$, Notazawa A (2013) The diversity of shell matrix proteins: genome-wide investigation of the pearl oyster, Pinctada fucata. Zool Sci 30:801-816

Miyashita T, Takagi R, Okushima M, Nakano S, Miyamoto H, Nishikawa E, Matsushiro A (2000) Complementary DNA cloning and characterization of pearlin, a new class of matrix protein in the nacreous layer of oyster pearls. Mar Biotechnol 2:409-418 
Montagnani C, Marie B, Marin F, Belliard C, Riquet F, Tayalé A, ..., Cochennec-Laureau N (2011) Pmarg-Pearlin is a matrix protein involved in nacre framework formation in the pearl oyster Pinctada margaritifera. Chembiochem 12:2033-2043

Owens L, Malham S (2015) Review of the RNA interference pathway in molluscs including some possibilities for use in bivalves in aquaculture. J Mar Sci Eng 3(1):87-99

Team, R. C. (2015). R: A language and environment for statistical computing [Internet]. Vienna, Austria: R Foundation for Statistical Computing; 2014. AQ21

Scoones SJR (1996) The development of the pearl sac in Pinctada maxima (Jameson, 1901) (Lamellibranchia:Pteriidae) and the implications for the quality of cultured pearls. Master of Science. The University of Western Australia, Perth, p 36e79

Shi Y, Yu C, Gu Z, Zhan X, Wang Y, Wang A (2013)

Characterization of the pearl oyster (Pinctada martensii) mantle transcriptome unravels biomineralisation genes. Mar Biotechnol 15 (2): $175-187$

Southgate PC (2008) Pearl oyster culture. In: Southgate PC, Lucas JS (Eds) The pearl oyster. Elsevier, Oxford, pp 231-272 AQ22

Southgate PC (2011) The pearl oyster culture. In: Southgate P, Lucas J (Eds.) The pearl Oyster. Elsevier Science Publishers BV, Amsterdam, p. 257 AQ23

Sudo S, Fujikawa T, Nagakura T, Ohkubo T, Sakaguchi K, Tanaka M, Nakashima K, Takahashi T (1997) Structures of mollusc shell framework proteins. Nature 387:563-564 
Suzuki M, Nagasawa H (2007) The structure-function relationship analysis of prismalin-14 from the prismatic layer of the Japanese pearl oyster, Pinctada fucata. FEBS J 274:5158-5166

Suzuki M, Nagasawa H (2013) Mollusk shell structures and their formation mechanism. Can J Zool 91:349-366

Suzuki M, Murayama E, Inoue H, Ozaki N, Tohse H, Kogure T, Nagasawa H (2004) Characterization of Prismalin-14, a novel matrix protein from the prismatic layer of the Japanese pearl oyster (Pinctada fucata). Biochem J 382:205-213

Suzuki M, Saruwatari K, Kogure T, Yamamoto Y, Nishimura T, Kato T, Nagasawa H (2009) An acidic matrix protein, Pif, is a key macromolecule for nacre formation. Science 325:1388-1390

Takeuchi T, Sarashina I, Iijima M, Endo K (2008) In vitro regulation of $\mathrm{CaCO} 3$ crystal polymorphism by the highly acidic molluscan shell protein Aspein. FEBS Lett 582:591-596

Tayalé A, Gueguen Y, Treguier C, Le Grand J, Cochennec-Laureau N, Montagnani C, Ky CL (2012) Evidence of donor effect on cultured pearl quality from a duplicated grafting experiment on Pinctada margaritifera using wild donors. Aquat Living Resour 25:269-280

Therneau TM, Atkinson B, Ripley B, Oksanen J, De'ath G (2013) mvpart: Multivariate partitioning R package version 16-1. http://CRAN.R-project.org/package=mvpart AQ24

Tsukamoto D, Sarashina I, Endo K (2004) Structure and expression of an unusually acidic matrix protein of pearl oyster shells. Biochem Biophys Res Commun 320:1175-1180

Wada K (1968) Machanism of growth of nacre in bivalvia. Bull Natl Pearl Resour Lab 13:1490-1539 
Wang N, Kinoshita S, Riho C, Maeyama K, Nagai K, Watabe S (2009) Quantitative expression analysis of nacreous shell matrix protein genes in the process of pearl biogenesis. Comp Biochem Physiol B: Biochem Mol Biol 154(3):346-350

Weiner S, Hood L (1975) Soluble protein of the organic matrix of mollusk shells: a potential template for shell formation. Science 190:987-989

Yan F, Jiao Y, Deng Y, Du X, Huang R, Wang Q, Chen W (2014) Tissue inhibitor of metalloproteinase gene from pearl oyster Pinctada martensii participates in nacre formation. Biochem Biophys Res Commun 450(1):300-305

Yano M, Nagai K, Morimoto K, Miyamoto H (2006) Shematrin: a family of glycine-rich structural proteins in the shell of the pearl oyster Pinctada fucata. Comp Biochem Physiol B Biochem Mol Biol 144(2):254-262

Zhan X, Gu Z, Yu C, Wen H, Shi Y, Wang A (2015) Expressed sequence tags 454 sequencing and biomineralisation gene expression for pearl sac of the pearl oyster, Pinctada fucata martensii. Aquac Res 46(3):745-758

Zhang G, Fang X, Guo X, Li L, Luo R, Xu F, Wang J (2012) The oyster genome reveals stress adaptation and complexity of shell formation. Nature 490:49-54

Zhao M, He M, Huang X, Wang Q (2014) A homeodomain transcription factor gene, PfMSX, activates expression of Pif gene in the pearl oyster Pinctada fucata. PLoS One 9(8):e103830

Zhu W, Fan S, Huang G, Zhang D, Liu B, Bi X, Yu D (2015) Highly expressed EGFR in pearl sac may facilitate the pearl formation in the pearl oyster, Pinctada fucata. Gene 566(2):201-211 
Livak KJ, \& Schmittgen TD (2001) Analysis of relative gene expression data using real-time quantitative PCR and the $2-\Delta \Delta C T$ method. methods, 25(4), 402-408

http://eproofing.springer.com/journals_v2/printpage.php?token=FQrWiRj1m3CYq5f6... 26/03/2018 